\title{
Evaluation of quality of the family health strategy in the Federal District
}

\author{
Avaliação da qualidade da estratégia saúde da família no Distrito Federal \\ La evaluación de la calidad de la Estrategia Salud de la Familia en Distrito Federal, Brasil
}

Helena Eri Shimizu'

ORCID: 0000-0001-5612-5695

Maíra Catharina Ramos"

ORCID: 0000-0003-3829-975X

'Universidade de Brasília. Brasília-DF, Brasil.

"Hospital Israelita Albert Einstein

How to cite this article:

Shimizu HE, Ramos MC. Evaluation of quality of the family health strategy in the Federal District. Rev Bras Enferm. 2019;72(2):367-74. doi: http://dx.doi.org/10.1590/0034-7167-2018-0130

\section{Corresponding Author:} Helena Eri Shimizu

E-mail: shimizu@unb.br

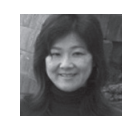

Submission: 15-03-2018

Approval: 18-08-2018

\section{ABSTRACT}

Aim: To evaluate quality of the Family Health Strategy (FHS) in the National Program for Improving Access and Quality of Primary Care in the Federal District (FD) from the perspective of users. Methods: Evaluative research carried out in 25 basic health units of the Federal District through a validated questionnaire assessing the following dimensions: access, gateway, bond, service range, coordination, family focus, community orientation, and health professionals. Results: Service provision, qualification of professionals, quality of professional-user relationship, and continuity of care were the best evaluated dimensions, while family approach, community approach, and access were the worst. Access to the FHS was found to be compromised, besides failing to establish itself as gateway to the FD health system. Conclusion: When they can access the local system, FD users do enjoy several services, but access is still a barrier, mainly because the very system is not prepared to meet users' needs/preferences. The dimensions regarding family focus and community orientation are precarious, which reveals the need for reflection on the care model adopted in the Federal District.

Descriptors: Primary Health Care; Health Services Research; Public Health Systems Research; Community Health Services; Surveys and Questionnaires.

\section{RESUMO}

Objetivo: Avaliar a qualidade da Estratégia Saúde da Família (ESF) participantes do no Programa Nacional de Melhoria do Acesso e da Qualidade da Atenção Básica do Distrito Federal (DF) na perspectiva dos usuários. Métodos: Pesquisa avaliativa realizada em 25 unidades básicas do Distrito Federal por meio do questionário validado que avalia as dimensões: acesso, porta de entrada, vínculo, elenco de serviço, coordenação, enfoque familiar, orientação comunitária e profissionais de saúde. Resultados: Foram melhores avaliadas as dimensões sobre oferta de serviços, qualificação dos profissionais, qualidade da relação profissional e usuário e a continuidade do atendimento, enquanto as piores foram o enfoque familiar, enfoque comunitário e o acesso. Observou-se que o acesso à ESF está comprometido, além de ter dificuldade de se configurar como porta de entrada principal para o sistema de saúde do DF. Conclusão: Os usuários do DF, quando conseguem acessar o sistema local, conseguem usufruir de diversos serviços, entretanto, o acesso ainda é uma barreira, sobretudo porque o próprio sistema não está preparado para atender as necessidades/preferências dos usuários. As dimensões concernentes ao enfoque familiar e à orientação para a comunidade são precárias, o que revela a necessidade de reflexão sobre o modelo de cuidado adotado no Distrito Federal.

Descritores: Atenção Primária à Saúde; Avaliação dos Serviços de Saúde; Pesquisa em Sistemas de Saúde Pública; Serviços de Saúde Comunitária; Inquéritos e Questionários.

\section{RESUMEN}

Objetivo: Evaluar la calidad de la Estrategia Salud de la Familia (ESF) de participantes en el Programa Nacional de Mejora del Acceso y la Calidad de la Atención Primaria del Distrito Federal (DF), desde la perspectiva de los usuarios. Métodos: Estudio de evaluación del cual participaron 25 unidades básicas del Distrito Federal mediante un cuestionario validado, que evaluó las siguientes dimensiones: acceso, vía de acceso, vínculo, equipo de servicio, coordinación, enfoque familiar, orientación comunitaria y profesionales de salud. Resultados: Las dimensiones mejor evaluadas fueron las sobre la oferta de servicios, la calificación de los profesionales, la calidad de la relación profesional y el usuario y la continuidad de la asistencia, mientras que el enfoque familiar, el enfoque comunitario y el acceso fueron las peores evaluadas. Se observó que el acceso a la ESF está comprometido, además de tener dificultades para configurarse como vía de acceso principal al sistema de salud del DF. Conclusión: Los usuarios en el DF, cuando logran acceder al sistema local, pueden obtener diversos servicios, sin embargo, el acceso sigue siendo una barrera, sobre todo porque el propio sistema no está preparado para atender a sus necesidades/preferencias. Las dimensiones con respeto al enfoque familiar y la orientación hacia la comunidad son precarias, lo que revela la necesidad de reflexionar sobre el modelo de la asistencia ofertada en el Distrito Federal.

Descriptores: Atención Primaria de Salud; Investigación en Servicios de Salud; Investigación en Sistemas de Salud Pública; Servicios de Salud Comunitaria; Encuestas y Cuestionarios. 


\section{INTRODUCTION}

Countries that have adopted Primary Health Care (PHC) as a basis for coordinating the health system have been successful in the quality of services provided to the population and with lower expenditures. In Brazil, since the creation of the Unified Health System (SUS), investments have been made in PHC, especially in the Family Health Strategy (FHS), for inducing transformation in the healthcare model.

In effect, studies have shown improvements in the FHS as regards reduction in infant mortality due to diarrhea ${ }^{(1-2)}$, respiratory diseases ${ }^{(3)}$ and malnutrition ${ }^{(4)}$, as well as reduction in hospitalizations due to care-sensitive causes and chronic diseases ${ }^{(5-6)}$, in addition to the expansion of vaccination coverage ${ }^{(7)}$, which points out that its consolidation is related to the improvement of its healthcare processes and integration into the health care network ${ }^{(8)}$.

In the Federal District in 2014, however, the estimated population coverage by the FHS was only $28.9 \%{ }^{(8)}$. The health secretariat recognizes that healthcare models, even with an organized, high-level density of services, have not been able to meet the health demands of the Brazilian population. In this perspective, the Healthy Brasilia Program foresees the strengthening of Primary Health Care in the Federal District by expanding FHS, as well as by restructuring and expanding $\mathrm{PHC}$ as the main gateway ordering health care networks ${ }^{(9)}$.

Despite the improvements in health conditions promoted by the expansion of FHS coverage, the quality of services provided to the population, as well as their capacity for re-organizing the system, are yet challenges to be achieved, given the fragility of PHC to establish itself as organizer of the health care network.

To that end, Starfield points out that PHC has essential attributes, which promote service quality and improve its capacity to interact with users and communities ${ }^{(10)}$. These are: first contact access and access whenever the user needs; longitudinality, which refers to the continuous relationship of the user with strong trust in the service; coordination, which includes articulation and integration of actions and services; integrality, which refers to all the promotion, prevention, cure and rehabilitation actions offered by the health system. The family approach refers to information about family factors related to the health-disease-illness process and the importance of the family as a subject of attention. Community orientation concerns the relevance of community health and cultural competence, which means understanding the cultural specificities of the community served ${ }^{(10)}$.

In this perspective, the evaluation of these attributes stands out as an important management tool that serves both to measure how the policy is achieving the expected results and to guide the improvement of any ongoing intervention ${ }^{(11)}$. Thus, user perception is important to produce information about the services rendered relevant to decision making.

In view of these challenges, the recent directives of the Ministry of Health in convergence with the implementation process of the National Primary Care Policy ${ }^{(12)}$ created, through ordinance No. $1654 / 2011^{(13)}$, which was revoked by ordinance No. 1645/2015 (14), the National Program for Improving Access and Quality of Primary Care (PMAQ- $A B)$, designed primarily to induce managers and teams to improve the quality of health services offered to users of the territory. The Program is considered as a strategy for affirming PHC as a welcoming and effective gateway to the Unified Health System ${ }^{(15)}$.
User-centered assessments have been an important field in the evaluation of services and systems, since users are the main actors involved in health systems and their perceptions are highly sensitive to changes in healthcare management model $s^{(16)}$. Furthermore, knowing how users evaluate the health service is key to improving actions and services to be developed, besides involving users in the management process and making them the subjects of the process ${ }^{(16)}$.

\section{AIM}

To evaluate the quality of the Family Health Strategy registered in the National Program for Improving Access and Quality of Primary Care in the Federal District, based on users' perception regarding the organization of services: accessibility, gateway, coordination, community services and guidance to the community, as well as caregiving dimensions: professional links and family approach.

\section{METHOD}

\section{Ethical aspects}

This study was submitted and approved by the Ethics Committee of the Teaching and Research Foundation of the Health Department of the Federal District. All of the participants signed a Free and Informed Consent Form, according to Resolution 466/12.

\section{Type of study}

Evaluation research, which is geared to value judgment of social practices, especially those resulting from a planned social action, such as health policies, programs and services ${ }^{(17)}$.

\section{Place of study}

The study was carried out with the Family Health Strategy teams of the Federal District, which joined the National Program for Improving Access and Quality of Primary Care. These units served 55,681 users.

\section{Data source}

To calculate sample size, the proportional division of users of rural and urban areas was considered, which totaled 382 users. The sample error adopted was 5\% and the confidence level $95 \%$.

We included users who had regularly attended any FHS unit for more than three months and who were over 18 years of age, and excluded those who had physical and mental conditions.

The analysis unit consisted of 353 users of 25 basic health units from 10 Administrative Regions of the Federal District, using a convenience criterion, considering acceptance for participation in the study. Three Units refused to participate, which resulted in the loss of 29 users.

\section{Collection and organization of data}

The Primary Care Assessment Tool (PCATool)(18) was used, which is a validated questionnaire composed of 87 questions associated with the following dimensions: 1) Accessibility: times and days of care, 
ease of consulting and obtaining medicines and how the population perceives the aspects of access; 2) Gateway: use of preventive medical consultation services and emergency care; 3) Bond: quality of relations between health professionals and population; 4) Service provision: types of primary care services offered by the units; 5) Coordination: articulation of actions that guarantee the quality in the continuity of care by professionals of the services and for consultations referred to specialists; 6) Family focus: consideration of family and family environment in service consultations; 7) Orientation to the community: regarding the service, it considers the social context of the health needs of the population in the planning of actions; 8) Health professionals: qualification of health service professionals.

\section{Data analysis}

Study participants answered a questionnaire with a likert scale, where never $=0$, almost never $=1$, sometimes $=2$, often $=3$, almost always $=4$, and always $=5$ ). The value of 0 was assigned to the worst performance and 5 to the best performance. A simple arithmetic mean score was obtained for each dimension evaluated, in a 0-5 scale. From this score it was possible to evaluate each attribute of basic attention according to users' experience of the service. Data analysis was carried out with Stata 12.0 and Excel 2013 software.

\section{RESULTS}

From the users' profile, Table 1 shows that there was a predominance of women, with a median level of education, low family income (up to four minimum wages), and unpaid family employment or unemployed.

Of the 8 dimensions of basic care, it can be seen in Table 2 that from those related to the organization of services: access (2.17) and community orientation (2.18) were the worst evaluated. And the dimensions services provision (4.99), coordination (3.92) and gateway (3.35) were the best evaluated.

Table 2 also shows that the caregiving dimensions: professionals (3.99) and bond (3.98) were well evaluated; yet the family approach (2.64) was negatively evaluated.

In the access dimension, three elements scored below one, namely: operating on weekends, operating after $6 \mathrm{pm}$ on at least one day of the week, and available telephone number to make appointments or ask for information while the health unit is closed. When asked about waiting time greater than 30 minutes for care, the obtained score was 4.19, indicating that, in general, the interviewed population always waits more than half an hour for care (Table 3 ).

Table 4 summarizes the evaluated elements of the services set dimension. Prenatal control (4.93), care for adults (4.89) and care for the elderly scored better, while attention to violence (1.81), education about domestic accidents (2.00), and mental health problems (2.37) were the worst services as perceived by users.

Table 5 presents the assessment of gateway, coordination, family focus and community orientation dimensions. About the gateway, users were asked if they visited the health unit for preventive control (vaccinating, measuring pressure, routine exams), or when they had a health problem, and also if, when they needed an appointment with a specialist, they first had to consult with the doctor of the unit they attended.
Table 1 - Characterization of the interviewed users, by urban and rural unit, Federal District, Brazil, 2014

\begin{tabular}{|c|c|c|}
\hline \multirow[b]{2}{*}{ Variable } & \multicolumn{2}{|c|}{ Unit Location } \\
\hline & $\begin{array}{c}\text { Urban } \\
(\%)\end{array}$ & $\begin{array}{c}\text { Rural } \\
\text { (\%) }\end{array}$ \\
\hline \multicolumn{3}{|l|}{ Age } \\
\hline Under 20 years & 3.3 & 2.1 \\
\hline From 20 to 39 years & 44.3 & 43.8 \\
\hline From 40 to 59 years & 44.3 & 34.7 \\
\hline From 60 to 79 years & 6.6 & 19 \\
\hline 80 years and over & 1.6 & 0.4 \\
\hline \multicolumn{3}{|l|}{ Sex } \\
\hline Male & 18 & 23.1 \\
\hline Female & 82 & 76.9 \\
\hline \multicolumn{3}{|l|}{ Schooling } \\
\hline Incomplete elementary & 24.6 & 22.3 \\
\hline Complete elementary & 13.1 & 9.5 \\
\hline Incomplete high school & 21.3 & 14.9 \\
\hline Complete high school & 31.2 & 34.3 \\
\hline Incomplete college & 4.9 & 4.6 \\
\hline College degree & 1.6 & 7 \\
\hline Postgraduate studies & - & 1.2 \\
\hline No schooling & 3.3 & 6.2 \\
\hline \multicolumn{3}{|l|}{ Income } \\
\hline Up to 1 minimum wage & 42.6 & 45 \\
\hline 2-4 minimum wages & 47.5 & 42.2 \\
\hline Over 5 minimum wages & 8.2 & 12.8 \\
\hline \multicolumn{3}{|l|}{ Occupation } \\
\hline Public server & 1.6 & 4.6 \\
\hline Employee with a formal contract & 9.8 & 28.9 \\
\hline Employee without salary & 9.8 & 7 \\
\hline Unpaid family employee & 14.8 & 24.4 \\
\hline Self-employed w/ establishment & 6.6 & 3.3 \\
\hline Self-employed w/o establishment & 3.3 & 6.6 \\
\hline Employer with fixed employees & 1.6 & 0.4 \\
\hline Unemployed & 18 & 11.2 \\
\hline Retired & 6.6 & 8.3 \\
\hline Pensioner & 3.3 & 2.5 \\
\hline Other & 23 & 2.9 \\
\hline \multicolumn{3}{|l|}{ Time attending unit } \\
\hline Between 3 and 11 months & 26.2 & 16.9 \\
\hline One to 4 years & 32.8 & 23.6 \\
\hline Five to 10 years & 23 & 18.2 \\
\hline More than 10 years & 18 & 41.3 \\
\hline
\end{tabular}

Source: Developed by authors

Regarding the coordination category, the worst evaluated item was the user's right to have access to his/her medical record (1.51). The best evaluated were possession of a user's identification document, as well as results of exams and immunization card at the time of consultation (4.87) and possession of medical record during the consultation by health professional (4.75).

Regarding the family approach, the worst evaluated item was professionals asking about the living conditions of the individual and family (1.34). The best-evaluated item was if during the consultation professionals asked about diseases of the family. Finally, on the community orientation dimension, home visits and knowledge of the most important health problems in the community were well evaluated by users. However, consulting the family to know if the available services meet the health problems was the worst evaluated. 
Table 2 - Scores assigned by users according to dimensions of Basic Attention, Federal District, Brazil, 2014

\begin{tabular}{|c|c|c|c|c|c|c|c|c|}
\hline \multirow[b]{2}{*}{ AR } & \multicolumn{8}{|c|}{ Assigned score [95\% Cl] } \\
\hline & Access & Gateway & Bond & Service Range & Coordination & Family Focus & $\begin{array}{l}\text { Community } \\
\text { Orientation }\end{array}$ & $\begin{array}{c}\text { Health } \\
\text { professionals }\end{array}$ \\
\hline Areal & $1.73[1.38-2.08]$ & $3.20[2.60-3.80]$ & $4.51[4.28-4.74]$ & $4.59[4.42-4.75]$ & $4.27[3.93-4.60]$ & 5 & $3.06[2.51-3.60]$ & $4.31[3.99-4.61]$ \\
\hline Brazlândia & $1.33[0.95-1.70]$ & $1.53[0.83-2.21]$ & $3.63[3.20-4.06]$ & $2.73[2.42-3.04]$ & $3.25[2.70-3.78]$ & $2.08[1.13-3.03]$ & $1.34[0.81-1.86]$ & $2.14[1.59-2.67]$ \\
\hline Ceilândia & $1.98[1.60-2.35]$ & $2.39[1.81-2.96]$ & $3.55[3.16-3.93]$ & $3.85[3.56-4.13]$ & $3.60[3.09-4.11]$ & $2.83[1.89-3.76]$ & $2.42[1.78-3.05]$ & $3.83[3.42-4.23]$ \\
\hline Estrutural & $2.86[2.66-3.06]$ & $3.83[3.54-4.10]$ & $4.05[3.88-4.21]$ & $4.50[4.39-4.60]$ & $4.00[3.77-4.21]$ & $2.59[2.13-3.04]$ & $1.87[1.56-2.16]$ & $4.05[3.86-4.23]$ \\
\hline Gama & $2.23[2.11-2.34]$ & $3.64[3.46-3.81]$ & $3.99[3.88-4.08]$ & $4.54[4.48-4.59]$ & $4.05[3.93-4.17]$ & $2.43[2.16-2.68]$ & $2.43[2.25-2.61]$ & $4.15[4.04-4.24]$ \\
\hline Itapoã & $2.19[1.56-2.92]$ & $3.39[2.39-4.38]$ & $4.40[4.00-4.80]$ & $4.99[4.95-5]$ & 4.32 [3.78-4.86] & 1.91 [0.59-3.12] & $0.81[0.30-1.30]$ & $4.77[4.61-4.92]$ \\
\hline Paranoá & $1.86[1.56-2.15]$ & $4.02[3.63-4.40]$ & $4.28[4.05-4.50]$ & $4.55[4.40-4.70]$ & $4.32[4.03-4.60]$ & $2.76[2.04-3.48]$ & 2.87 [2.39-3.34] & $4.63[4.47-4.78]$ \\
\hline Samambaia & 1.91 [1.38-2.44] & $4.19[3.50-4.86]$ & $4.39[4.02-4.75]$ & $4.72[4.55-4.89]$ & 4.55 [4.16-4.93] & 3.89 [2.89-4.87] & $2.29[1.44-3.12]$ & 4.38 [3.92-4.82] \\
\hline São Sebastião & $1.23[0.90-1.55]$ & $2.14[1.55-2.72]$ & $3.79[3.42-4.14]$ & $1.94[1.67-2.21]$ & $2.99[2.48-3.48]$ & $2.74[1.84-3.63]$ & $1.77[1.32-2.22]$ & $3.00[2.58-3.41]$ \\
\hline Sobradinho & $1.98[1.77-2.17]$ & $2.61[2.25-2.96]$ & $3.88[3.68-4.06]$ & $3.51[3.34-3.67$ & 3.57 [3.31-3.81] & $2.40[1.94-2.84]$ & $2.06[1.75-2.35]$ & 3.83 [3.62-4.03] \\
\hline FD & 2.17 [2.09-2.25] & $3.35[3.20-3.51]$ & $3.98[3.88-4.07]$ & $4.26[4.16-4.36]$ & 3.92 [3.83-4.02] & $2.64[2.48-2.81]$ & $2.18[2.05-2.32]$ & $3.99[3.88-4.10]$ \\
\hline
\end{tabular}

Legend: 95\% Cl - 95\% Confidence Interval; AR - Administrative Region; FD - Federal District

Source: Developed by authors

Table 3 - Scores assigned by users to the access dimension, Federal District, Brazil, 2014.

\begin{tabular}{lc}
\hline Access & Score \\
\hline
\end{tabular}

Do you find it easy to get a medical consultation in this health care unit?

Do you think you can get a (non-urgent) medical consultation at this health facility within 24 hours?

Is this facility/center/unit open during the weekends?

Is this facility/center/unit open after $6 \mathrm{pm}$ at least one day during the week?

During the regular operating period of this facility/center/unit, is there an available telephone number to make appointments or ask for information?

When this facility/center/unit is closed, is there an available telephone number to make appointments or ask for information?

Do you usually have to wait more than 30 minutes in this health unit before being seen by a health professional?

Source: Developed by authors

Table 4 - Scores assigned by users to the services set dimension, Federal District, Brazil, 2014

\begin{tabular}{lc}
\hline Services & Score \\
\hline Vaccinations for children & 4.44 \\
Child care & 4.83 \\
Adult care & 4.89 \\
Elderly care & 4.88 \\
Prenatal control & 4.93 \\
Family planning services & 4.62 \\
Attention to sexually transmitted diseases (e.g. AIDS, syphilis) & 4.30 \\
Tuberculosis control program & 4.08 \\
Controls/treatment of epidemic diseases (e.g. dengue, malaria) & 4.22 \\
Counseling for chronic diseases (arthritis, asthma, heart disease) & 4.21 \\
Treatment/control of diabetes & 4.72 \\
Treatment/control of hypertension or high blood pressure & 4.82 \\
Treatment of minor injuries & 4.31
\end{tabular}

\begin{tabular}{lc}
\hline Services & Score \\
\hline Advice on alcohol and tobacco use & 3.64 \\
Mental health problems & 2.37 \\
Advice on diet or nutrition & 3.74 \\
Advice on physical activity & 3.75 \\
Education on hygienic preparation of water and food & 3.24 \\
Domestic violence education & 1.81 \\
Home accident education & 2.00 \\
Preventive dental education (tooth brushing, oral hygiene) & 3.5 \\
Dental care & 3.4 \\
\hline Source: Developed by authors. &
\end{tabular}

Table 5 - Scores assigned by users to dimensions, Federal District, Brazil, 2014

Dimensions Score

Gateway

In general, when you or your family needs some preventive health care (vaccinating, measuring blood pressure, routine tests), do you 3.92 come to this facility/center/unit?

When you or your family has a health problem, do you usually come to this facility/center/unit?

Except in emergency cases, do you normally have to make an appointment at this facility/center/unit before consulting with a specialist?

Coordination

Do you receive the results of your laboratory tests?

Do you bring the results of your laboratory tests to this facility/ center/unit?

Are you notified of the scheduling of your return visit to know the results of your lab tests?

When you come to this facility/center/unit, do you bring documents, medical records, test results or requests, immunization cards, etc.?

Does the professional of this facility/center/unit always have your medical records available when you are being seen or examined?

Do the professionals of this facility/center/unit allow you to see your medical record?

core

\section{2}

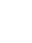


Table 5 (concluded)

\begin{tabular}{|c|c|}
\hline Dimensions & Score \\
\hline \multicolumn{2}{|l|}{ Family Focus } \\
\hline $\begin{array}{l}\text { During the consultation, do the professionals of this unit usually } \\
\text { ask about your living conditions and those of your family } \\
\text { (unemployment, availability of drinking water, basic sanitation etc.)? }\end{array}$ & 1.34 \\
\hline $\begin{array}{l}\text { During the consultation do the professionals of this facility/ } \\
\text { center/unit usually ask for information on diseases of other } \\
\text { family members? }\end{array}$ & 3.95 \\
\hline \multicolumn{2}{|l|}{ Community Orientation } \\
\hline $\begin{array}{l}\text { Are you or your family consulted to know if the services of this } \\
\text { facility/center/ unit meet your health problems? }\end{array}$ & 0.95 \\
\hline $\begin{array}{l}\text { Do you think that the professionals of this facility/center/ } \\
\text { unit know about the most important health problems in your } \\
\text { community? }\end{array}$ & 3.18 \\
\hline Does this facility/center/unit offer services in schools? & 2.5 \\
\hline $\begin{array}{l}\text { How often do the professionals in this facility/center/unit } \\
\text { make home visits? }\end{array}$ & 2.78 \\
\hline $\begin{array}{l}\text { Do you think this facility/center/unit works with others } \\
\text { groups to carry out activities that improve the living } \\
\text { conditions of your community? }\end{array}$ & 2.19 \\
\hline
\end{tabular}

\section{DISCUSSION}

In this study, the predominance of women as users of FHS services was observed, corroborating other studies ${ }^{(19)}$, which reaffirm the role of women as the main responsible for health care. Regarding the level of schooling, many of them were found to have a low level, which makes it difficult for these women to enter the formal labor market with better remunerations ${ }^{(19)}$.

Access to the FHS teams in the FD is compromised, with a long waiting period for consultation, limited working hours (Monday to Friday during business hours), the impossibility of solving urgent health problems and by telephone. These stand as organizational barriers related to the access to basic units that has commonly compromised the quality of $\mathrm{PHC}^{(20-21)}$.

The access problem undermines advances in the scope of integrality, besides posing fragility to the management and organization of the service network ${ }^{(22)}$. In this regard, it is important to highlight that the actions of reception and humanization in the coordination of care are essential in $\mathrm{PHC}$ and tend to become fragile when other mechanisms of access to services are not timely and continuous so as to guarantee access to other healthcare levels ${ }^{(21)}$.

In addition, it was observed that FHS in the FD has difficulty in establishing itself as the main gateway to the health system. In this logic, studies indicate that greater or lesser connection of the population to services to obtain diagnostic and therapeutic support consultations is characterized as a challenge to the search for integral care in $\mathrm{PHC}^{(20-}$ 21). Another factor that makes it difficult to adopt the FHS as a gateway is the existence of other forms of access to services, acting concurrently. In this regard, it is necessary to reaffirm the FHS as an essential gateway for the organization of access in an integrated network ${ }^{(23)}$.

In order to strengthen the care model, PHC must be accessible, open and take into account users' health demands from care actions between caregiving levels, with ordered flows and counterflows, so as to intervene on social determinants and guarantee the integrality of care.

Regarding the coordination dimension, actions related to access to laboratory tests are satisfactory, but there is a certain difficulty for users to receive communication about the tests results received by the services. As for medical records, the services do have them, but users cannot access them. Services are hardly organized to be centered in the user, that is, to count on their more active participation in the caring process.

In general, the FHS units of the FD have a good set of services, that is, when users are able to enter health services, they can take advantage of actions commonly offered by $\mathrm{PHC}$, from vaccination, chronic disease control and family planning to dental care, which can aid in prevention and health promotion.

The link was positive in the relationship between users and health professionals, reaffirming the importance of this attribute in the continuity of health actions and the longitudinality of care $^{(24)}$. In addition, the way professionals relate to the community was evaluated as satisfactory, although the absence, mainly of physicians, and the lack of ability to solve problems were indicated as factors causing dissatisfaction.

It was observed that for FHS reorganization, the focus on family and community must be the central axis in care ${ }^{(25)}$. However, both these aspects remain as the greatest fragilities, since the focus on the individual and the disease is strongly present in the $\mathrm{PHC}$ context, which requires changes in care models, considering the socio-cultural context and the integrality of care. The maintenance of the individual clinical model may be associated with insufficient curricular content addressing the biological issues related to the context of social determination inherent to the care offer ${ }^{(24)}$.

Community orientation implies recognizing that all health needs of the population occur in a particular social context, and it is the teams' responsibility to shift to a more active behavior, extending their actions to the entire community ${ }^{25}$. Thus, working together with the population on plans to deal with problems and conditions of risk to the health of the population is essential, so that the coordination of care is carried out in a universal, integral and equitable way ${ }^{(25)}$.

Other studies on the assessment of primary care from user perspective were identified in the literature ${ }^{(26-29)}$. Access and family orientation dimensions were evaluated below the cut-off point in two studies ${ }^{(26,29)}$. The access dimension is the most sensitive to user perception and testifies how the FHS is, in fact, guiding the system for $\mathrm{PHC}$, while the family orientation dimension brings the information of the care being focused or not on the family served and reflects the service's approach ${ }^{(16)}$. In both dimensions, inadequacy to the FHS philosophy is highlighted ${ }^{(26)}$.

According to a literature review on the evaluation of performance of primary care using the PCATool, the access attribute shows a poor performance, reflecting possible territorial and organizational vulnerabilities of the service, such as reduced working hours and long waiting queues, while the longitudinality attribute was the third best evaluated, demonstrating that there is a relation between user and service ${ }^{(30)}$. Both results were close to those reported here.

Assessing the quality of $\mathrm{PHC}$ from a user perspective effectively contributes to the identification of health care network failures, supporting the shared decision-making process and assisting in the necessary changes to the professional practice and work process involved ${ }^{(26,28)}$. Moreover, such an evaluation contributes to the construction of interventions that are appropriate to the local reality ${ }^{(28)}$, besides being a tool for empowering the population ${ }^{(16)}$. 
Based on such principles as universality, integrality and equity, the family health proposal was conceived as a strategy to change the care model that, in its systemic perspective, is articulated in three dimensions: managerial - concerning the reorganization of actions and services; organizational - articulations between services; and technical-supportive - relationships between professionals/workers and care subjects ${ }^{(25)}$. In this sense, the need for continuing the debate about the necessary changes in management and attention models in the FHS becomes quite clear.

\section{Limitations of the study}

Some limitations can be acknowledged in this study. The feeling of gratitude (gratitude bias) can hinder a critical assessment by users about the care received. In addition, it presents common biases of transversal studies.

\section{Contributions to the nursing area}

Finally, the contribution of nursing in the evaluation of FHS is highlighted, since the nursing team plays a fundamental role in basic care. Thus, it is increasingly necessary to deepen the discussions about how the nursing team is needed in key work processes and in the management of care for qualification of basic care and especially in the Family Health Strategy ${ }^{(31-32)}$.

\section{CONCLUSION}

From users' perspective, when they manage to enter the health system they can enjoy several services. However, access is still a barrier, especially because the system itself is not prepared to meet their needs/preferences. In addition, relations with families and their territory/community are still somewhat precarious. Both these cases reflect the need to deepen the discussion of the care model that has been adopted in the FD.

In addition, this study indicates the need to analyze more deeply the barriers to integral care in the Federal District, as well as the key posts to be worked for the provision of quality service to the population. Finally, user-centered assessments, especially in the perspective of basic care, should not be punctual tools; the potential of the continuous use of such action is seen as a way of diagnosing the quality of the services provided, in order to support actions, policies and health programs.

\section{ACKNOWLEDGEMENTS}

We are grateful to Paloma Ribeiro Pires Simas and Yamila Comes for their contribution and final revision of the manuscript.

\section{FINANCIAL SUPPORT}

Conselho Nacional de Ciência e Tecnologia.

\section{REFERENCES}

1. Ceccon RF, Bueno ALM, Hesler LZ, Kirsten KS, Portes VDM, Viecili PRN. Infant mortality and Family Health units in the Brazilian Federation, 1998-2008. Cad Saúde Coletiva[Internet]. 2014[cited 2017 Oct 21];22(2):177-83. Available from: http://www.scielo.br/pdf/ cadsc/v22n2/1414-462X-cadsc-22-02-00177.pdf

2. Chung A, Fonchezatto A. Impacto do Programa Saúde da Família sobre indicadores de saúde infantil em municípios do Rio Grande do Sul[Internet]. 2015[cited 2017 Oct 21];343-62. Available from: https://revistas.fee.tche.br/index.php/ensaios/article/viewFile/3515/3598

3. Victora CG, Aquino EML, Leal MC, Monteiro CA, Barros FC, Szwarcwald CL. Saúde de mães e crianças no Brasil: progressos e desafios. Lancet[Internet]. 2011[cited 2017 Oct 19];32-46. Available from: http://bvsms.saude.gov.br/bvs/artigos/artigo_saude_brasil_2.pdf

4. Rasella D, Aquino R, Santos CAT, Paes-Sousa R, Barreto ML. Effect of a conditional cash transfer programme on childhood mortality: a nationwide analysis of Brazilian municipalities. The Lancet[Internet]. 2013[cited 2017 Oct 19];382(9886):57-64. Available from: https://www. thelancet.com/journals/lancet/article/PIIS0140-6736(13)60715-1/fulltext

5. Rasella D, Harhay MO, Pamponet ML, Aquino R, Barreto ML. Impact of primary health care on mortality from heart and cerebrovascular diseases in Brazil: a nationwide analysis of longitudinal data. BMJ[Internet]. 2014[cited 2017 Oct 19];349(g4014):1-10. Available from: https:// www.bmj.com/content/349/bmj.g4014.full.pdf

6. Guimarães TMR, Alves JGB, Tavares MMF. Impact of immunization measures by the Family Health Program on infant mortality from preventable diseases in Olinda, Pernambuco State, Brazil. Cad Saúde Pública[Internet]. 2009[cited 2018 Feb 16];25(4):868-76. Available from: http://www.scielo.br/pdf/csp/v25n4/18.pdf

7. Fausto MCR, Giovanella L, Mendonça MHM, Seidl H, Gagno J. The position of the Family Health Strategy in the health care system under the perspective of the PMAQ-AB participating teams and users. Saúde em Debate[Internet]. 2014[cited 2017 Nov 5];38(SPE):13-33. Available from: http://www.scielo.br/pdf/sdeb/v38nspe/0103-1104-sdeb-38-spe-0013.pdf Portuguese

8. Sousa NP, Rehem TCMSB, Santos WS, Santos CE. Hospitalizations sensitive to primary health care at a regional hospital in the Federal District. Rev Bras Enferm[Internet]. 2016[cited 2017 Nov 5];69(1):106-13. Available from: http://www.scielo.br/pdf/reben/v69n1/en_0034-7167reben-69-01-0118.pdf

9. Brasil. Secretaria de Estado de Saúde. Programa Brasília Saudável. O Fortalecimento da Atenção Primária à Saúde no DF[Internet]. Brasília: Secretaria de Estado de Saúde; 2016 [cited 2017 Oct 23]. Available from: http://www.coren-df.gov.br/site/wp-content/uploads/2016/06/ BRASILIA_SAUDAVEL_DOCUMENTO_REFERENCIAL.pdf

10. Starfield B. Atenção primária: equilíbrio entre necessidades de saúde, serviços e tecnologia. Brasília: UNESCO, Ministério da Saúde; 2002. 
Available from: https://www.nescon.medicina.ufmg.br/biblioteca/imagem/0253.pdf

11. Malta DC, Santos MAS, Stopa SR, Vieira JEB, Melo EA, Reis AAC. Family health strategy coverage in Brazil, according to the National Health Survey, 2013. Cienc Saude Coletiva[Internet]. 2016[cited 2017 Nov 5];21(2):327-38. Available from: http://www.scielo.br/pdf/csc/v21n2/ en_1413-8123-csc-21-02-0327.pdf

12. Ministério da Saúde (BR). Política nacional de atenção básica[Internet]. Brasília: Ministério da Saúde; 2012[cited 2017 Oct 23]. Available from: http://189.28.128.100/dab/docs/publicacoes/geral/pnab.pdf

13. Brasil. Ministério da Saúde. Portaria no 1.654, de 19 de julho de 2011 [Internet]. Brasília: Ministério da Saúde; 2012 [cited 2017 Oct 23 ]. Available from: http://bvsms.saude.gov.br/bvs/saudelegis/gm/2011/prt1654_19_07_2011.html.

14. Brasil. Ministério da Saúde. Portaria no 1.645, de 2 de outubro de 2015[Internet]. Brasília: Ministério da Saúde; 2015 [cited 2017 Oct 21 ]. Available from: http://bvsms.saude.gov.br/bvs/saudelegis/gm/2015/prt1645_01_10_2015.html.

15. Pinto HA, Sousa A, Florêncio AR. The National Program for Improving the Access and Quality of Primary Care: Reflections on the program design and deployment process. Rev Eletrônica Comun Informaçao Inovaçao em Saúde[Internet]. 2012[cited 2018 Feb 12];6(2). Available from: https://www.reciis.icict.fiocruz.br/index.php/reciis/article/view/498/pdf_305

16. Paiva MBP de, Mendes W, Brandão AL, Campos CEA. [A contribution to the assessment of the Primary Health Care in the user's viewpoint]. Physis Rev Saúde Coletiva[Internet]. 2015[cited 2017 Oct 21];25(3):925-50. Available from: http://www.scielo.br/pdf/physis/v25n3/01037331-physis-25-03-00925.pdf Portuguese

17. Vieira-da-Silva LM. Avaliação de políticas e programas de saúde. Rio de Janeiro: Fiocruz; 2014. 110p.

18. Harzheim E, Oliveira MMC, Agostinho MR, Hauser L, Stein AT, Gonçalves MR, et al. Validation of the Primary Care Assessment Tool: PCAToolBrazil for adults. Rev Bras Med Fam e Comunidade[Internet]. 2013[cited 2018 Feb 13];8(29):274-84. Available from: https://www.rbmfc.org. $\mathrm{br} / \mathrm{rbmfc} / \mathrm{article} / \mathrm{view} / 829$

19. Albuquerque MSV, Lyra TM, Farias SF, Mendes MFM, Martelli PJL. [Accessibility to health services: an analysis of the Primary Care in the state of Pernambuco]. Saúde Em Debate[Internet]. 2014[cited 2018 Feb 13];38(SPE):182-94. Available from: http://www.scielo.br/pdf/sdeb/ v38nspe/0103-1104-sdeb-38-spe-0182.pdf Portuguese

20. Cotta RMM, Prates LL, Costa GD, Avelar PS, Machado JC, Mendonça ET, et al. Performance of primary health care according to PCATool instrument: a systematic review. Ciênc. saúde coletiva[Internet]. 2017[cited 2018 Feb 13];22(6):1881-93. Available from: http://www.scielo. $\mathrm{br} / \mathrm{pdf} / \mathrm{csc} / \mathrm{v} 22 \mathrm{n} 6 / \mathrm{en} \_1413-8123-\mathrm{csc}-22-06-1881 . p d f$

21. Silva KL, Medeiros CS. Factors involved in the implementation of the Family Health Strategy in brazilian municipalities. Rev APS[Internet]. 2015[cited 2018 Feb 13];18(3):378-89. Available from: https://aps.ufjf.emnuvens.com.br/aps/article/viewFile/2506/901

22. Brandão AL da RB, Giovanella L, Campos CEA. Avaliação da atenção básica pela perspectiva dos usuários: adaptação do instrumento EUROPEP para grandes centros urbanos brasileiros. Ciênc Saúde Coletiva[Internet]. 2013 [cited 2018 Apr 3];18(1):103-14. Available from: http://www.scielo.br/pdf/csc/v18n1/12.pdf

23. Arantes LJ, Shimizu HE, Merchán-Hamann E. The benefits and challenges of the Family Health Strategy in Brazilian Primary Health care: a literature review. Cienc Saude Coletiva[Internet]. 2016[cited 2018 Apr 3];21(5):1499-509. Available from: http://www.scielo.br/pdf/csc/ v21n5/en_1413-8123-csc-21-05-1499.pdf

24. Reichert APS, Leônico ABA, Toso BRG, Santos NCCB, Vaz EMC, Collet N. Family and community orientation in children's primary healthcare. Cienc Saude Coletiva[Internet]. 2016[cited 2018 Feb 13];21(1):119-27. Available from: http://www.scielo.br/pdf/csc/v21n1/en_1413-8123csc-21-01-0119.pdf

25. Silva CS, Paes NA. Satisfaction of Hypertensive Users and Professionals Based on Primary Care Essential Attributes. Rev Bras Ciênc Saúde[Internet]. 2017[cited 2018 Feb 13];21(3):229-38. Available from: http://www.periodicos.ufpb.br/index.php/rbcs/article/ viewFile/24192/17789

26. Oliva ACD de, Moura CMR, Lima CA, Costa FM, Rocha JFD. Evaluation of attributes of primary health care from the perspective of the user. Rev Uniabeu[Internet]. 2015[cited 2017 Oct 21];8(18):196-208. Available from: http://revista.uniabeu.edu.br/index.php/RU/article/ view/1750

27. Paula FA, Silva CCR, Santos DF, Martins-Filho OA, Andrade RA. Evaluation of adult health care in a city pole of Vale do Jequitinhonha (MG). Saúde Em Debate [Internet]. 2015[cited 2018 Apr 3];39(106):802-14. Available from: http://www.scielo.br/pdf/sdeb/v39n106/0103-1104sdeb-39-106-00802.pdf

28. Silva CSO, Fonseca ADG, Souza LPS, Siqueira LG, Belasco AGS, Barbosa DA. The comprehensive nature of primary health care: evaluation from the user standpoint. Ciênc Saúde Coletiva[Internet]. 2014[cited 2017 Oct 19];19(11):4407-15. Available from: http://www.scielo.br/pdf/ csc/v19n11/1413-8123-csc-19-11-4407.pdf

29. Paula WKAS, Samico IC, Caminha MFC, Filho MB, Silva SL. Primary health care assessment from the users' perspectives: a systematic review. Rev Esc Enferm USP[Internet]. 2016[cited 2018 Feb 13];50(2):335-40. Available from: http://www.scielo.br/pdf/reeusp/v50n2/0080-6234reeusp-50-02-0335.pdf

30. Prates ML, Machado JC, Silva LS, Avelar PS, Prates LL, Mendonça ET, et al. Desempenho da Atenção Primária à Saúde segundo o instrumento PCATool: uma revisão sistemática. Ciênc Saúde Coletiva [Internet]. 2017 [em 2018 Feb 13];22(6):1881-93. Disponível em: http://www.scielo. br/pdf/csc/v22n6/en_1413-8123-csc-22-06-1881.pdf 
31. Shimizu HE, Trindade JS, Mesquita MS, Ramos MC. Evaluation of the Responsiveness Index of the Family Health Strategy in rural areas. Rev Esc Enferm USP[Internet]. 2018[cited 2018 May 4];52(e03316):1-7. Available from: http://www.scielo.br/pdf/reeusp/v52/en_0080-6234reeusp-S1980-220X2017020203316.pdf

32. Galiza FT, Bezerra ALS, Oliveira ASS, Felipe GF, Fernandes MC, Lima MA. Management of the nursing care in the family health strategy. J Nurs UFPE Line[Internet]. 2016[cited 2018 Feb 13];10(11):4075-81. Available from: https://periodicos.ufpe.br/revistas/revistaenfermagem/article/ view/11493/13354 